Paulina MATERA

Uniwersytet Łódzki

paulinamatera@uni.lodz.pl

\title{
INTERESY PAŃSTW A DZIAŁALNOŚĆ AMERYKAŃSKICH KORPORACJI MIĘDZYNARODOWYCH W LATACH 60. I 70. XX WIEKU
}

ABSTRACT The national interests and the activities of the American international corporations in the 1960s and $1970 \mathrm{~s}$

The main purpose of the article is to analyze the influence of international corporations on both domestic and foreign policy of the home and host countries as well as on intergovernmental relations. In the 1960s. and the 1970s. the predominant role of the US enterprises could be observed. Those companies invested mostly in the EC countries. They were welcomed there after the WWII, but the host countries felt growing concerns. They started to perceive the activities of the American enterprises as a challenge to national interest and even the national sovereignty. Therefore the actions to prevent foreign dominance were undertaken and the politicization of those matters was quite frequent. Also the authorities of the United States tried to control excessive capital flows and the transfer of certain goods and technology to the „enemy countries”. Moreover, the American corporations were reluctant to the unnecessary links with the US government as they wanted to avoid its impact on their activities.

Keywords: international corporations, interdependence between nation states and the corporations, American investments in Western Europe

Słowa kluczowe: korporacje międzynarodowe, współzależność państw narodowych i korporacji, inwestycje amerykańskie w Europie Zachodniej 
W ramach badań międzynarodowej ekonomii politycznej korporacje działające w wielu krajach są postrzegane jako istotni aktorzy stosunków międzynarodowych. Celem artykułu jest ukazanie wpływu działalności tych firm na politykę wewnętrzną ich krajów macierzystych i przyjmujących je oraz na relacje międzyrządowe w latach 60. i 70. XX wieku. Zostaną również ukazane najważniejsze aspekty interakcji przedsiębiorstw z władzami państw narodowych.

Korporacje międzynarodowe, według definicji ONZ, są to firmy, które posiadają środki produkcji lub świadczenia usług poza granicami kraju, z którego pochodzą ${ }^{1}$. W literaturze, także polskiej, występuje czasem rozróżnienie na przedsiębiorstwa transnarodowe i wielonarodowe. Dotyczy ono struktury własności i stopnia uzależnienia przedsiębiorstwa od jednostki macierzystej. Korporacje transnarodowe są określane jako prowadzace dziatalność gospodarcza o zasiegu międzynarodowym oraz [...] posiadające co najmniej $w$ dwóch krajach swoje filie bądź oddziaty, będacce w catości lub w części wtasnościa przedsiębiorstwa macierzystego i dziatajace pod jego kontrolą ${ }^{2}$. Natomiast korporacje wielonarodowe są definiowane jako takie, w których firma macierzysta ma tylko część aktywów, a resztę posiadają inne przedsiębiorstwa, najczęściej z kraju, w którym ono funkcjonuje ${ }^{3}$. Według tego podziału w artykule opisywane są najczęściej przypadki działalności firm transnarodowych. Jednak w przedstawionym okresie częstą praktyką było pożyczanie przez przedsiębiorców amerykańskich pieniędzy na działalność zagraniczną w kraju przyjmującym. Zgadzali się także na przejmowanie przez obce rządy pakietów ich akcji i tworzyli spółki joint ventures. Warto także zauważyć, że autorzy amerykańscy i europejscy, analizujący w latach 60. i 70. XX wieku działalność tego typu korporacji, nie wprowadzali żadnych rozróżnień, stosując określenie „korporacje wielonarodowe” (multinational corporations) dla wszystkich opisanych powyżej rodzajów firm. Zakładali, że są to organizacje biznesowe, określonego pochodzenia narodowego [podkr. P.M.], których dziatania zlokalizowane sq w więcej niżjednym kraju4. Także we współczesnych pracach, zarówno polskich, jak i zagranicznych, najczęściej pojawia się to określenie w powyższym rozumienius ${ }^{5}$ Jednak w celu uniknięcia wszelkich wątpliwości w artykule będzie stosowany najszerszy termin: „korporacje międzynarodowe”.

Pisząc o firmach amerykańskich, przyjęłam kryterium stopnia utożsamiania się ich ze Stanami Zjednoczonymi i zależności od centrali tam ulokowanej. Te współzależno-

Multinational Corporations in World Development, United Nations, Department of Economic and Social Affairs, [online] http://unctc.unctad.org/data/e73iia1 1a.pdf, 22 III 2014.

2 A. Makać, Wspótczesna gospodarka światowa. Jej istota i struktura, [w:] Przemiany we wspótczesnej gospodarce światowej, red. nauk. E. Oziewicz, Warszawa 2006, s. 16-17.

Tamże, s. 17.

S.J. Korbin, Sovereignty@Bay. Globalization, Multinational Enterprise, and the International Political System, [w:] Oxford Handbook of International Business, red. A.M. Rugman, T.L. Brewer, Oxford 2009, s. 172 .

5 Zob. np.: R. Gilpin, Global Political Economy. Understanding the International Economic Order, Princeton 2001, s. 278; J. Świerkocki, Zarys międzynarodowych stosunków gospodarczych, Warszawa 2004, s. 93. 
ści były bardzo duże, gdyż jak pisze Stephen Korbin: narodowości i kontrola większości korporacji byty narodowe bardziej niz międzynarodowe ${ }^{6}$. Przedsiębiorstwa musiały również dostosowywać się do prawa obowiązującego w kraju macierzystym, a ich działalność była uwarunkowana jego polityką na arenie międzynarodowej. $Z$ drugiej strony korporacje były postrzegane jako ważni aktorzy stosunków międzynarodowych, gdyż posiadając potężny potencjał gospodarczy, rozwijając nowoczesne technologie i techniki zarządzania, w coraz większym stopniu wpływały na gospodarkę światową i na politykę poszczególnych państw narodowych.

Jack Behrman stwierdził, że można było wyróżnić dwa podejścia szefów korporacji do działalności za granicą. Część z nich zakładała, że firma działa w ramach wielu narodowych gospodarek i powinna traktować każdą z nich jako odrębny organizm, zwracając uwagę na interesy danego kraju, dając większą swobodę działania poszczególnym filiom. Inni właściciele stawiali na pierwszym miejscu interes firmy. Zakładając, że nie da się pogodzić interesów różnych krajów, dążyli do centralizacji i uzgadniania jednolitej strategii. Pierwsze podejście redukowało problemy w relacjach z krajem przyjmującym, natomiast $\mathrm{w}$ drugim przypadku nieporozumienia czasem przenosiły się na poziom międzypaństwowy ${ }^{7}$.

\section{PRZEWAGA KORPORACJI AMERYKAŃSKICH W LATACH 50. I 60. XX WIEKU}

Korporacje międzynarodowe, w różnych formach i zakresie, na skalę globalną zaczęły funkcjonować najprężniej pod koniec XIX wieku, prowadząc działalność handlową i lokując bezpośrednie inwestycje za granicą. Okres dwóch wojen światowych, a także kryzys gospodarczy lat 30. XX wieku, powodujący wzrost tendencji protekcjonistycznych, zahamował ich aktywność ${ }^{8}$. Jednak po II wojnie światowej, już w latach 50 . XX wieku korporacje międzynarodowe stawały się, obok państw, najważniejszymi podmiotami handlowymi i inwestycyjnymi. Należy przy tym zaznaczyć, że początkowo dominowały firmy ze Stanów Zjednoczonych. Po II wojnie światowej kolejne administracje promowały ekspansję bezpośrednich inwestycji zagranicznych (BIZ) do krajów postrzeganych jako sojusznicze. Powodowało to dynamiczny wzrost ich wartości: w latach 1950-1960 z 11,8 mld USD do 31,9 mld USD. Inwestowano głównie w przemysł (33\%) i w przetwarzanie ropy naftowej (29\%). W latach 60. XX wieku ponad 60\% BIZ pochodziło z USA?.

$6 \quad$ S.J. Korbin, Sovereignty@Bay..., s. 187. Tłumaczenia tekstów obcojęzycznych, jeśli nie zaznaczono inaczej: P. Matera.

7 J.N. Behrman, National Interests and the Multinational Enterprise. Tensions Among the North Atlantic Countries, Eaglewood Clifs 1970, s. 1-2.

8 A. Jarczewska-Romaniuk, Relacjepolityki i ekonomii w procesie globalizacji, [w:] Globalizacja a stosunki międzynarodowe, red. E. Haliżak, R. Kuźniar, J. Symonides, Bydgoszcz-Warszawa 2004, s. 34-35.

9 J.S. Nye, Multinationals. The Game and the Rules. Multinational Corporations in World Politics, „Foreign Affairs” 1974, Vol. 53, nr 1, s. 171. 
W 1967 roku wartość produkcji amerykańskich korporacji międzynarodowych wynosiła 120 mld USD. W 1969 roku z 20 największych firm przemysłowych świata 18 pochodziło z USA. W 1971 roku firmy i banki z tego kraju posiadały blisko 70\% krótkoterminowych, płynnych aktywów prywatnych instytucji międzynarodowych ${ }^{10}$. Oznaczało to bardzo duży wpływ na gospodarkę światową. Firmy te mogły bowiem wywołać poważny kryzys, przenosząc swobodnie inwestycje do różnych krajów. Decydując się na ulokowanie środków w danym państwie, liczyły na zmniejszenie kosztów produkcji, zwiększenie efektywności i zdobycie nowych rynków zbytu. Do 1969 roku amerykańskie korporacje produkowały za granicą towary o wartości pięciokrotnie przewyższającej wartość eksportu USA. Podstawowa aktywność Stanów Zjednoczonych w międzynarodowych transakcjach gospodarczych dokonywała się przez te przedsiębiorstwa, a nie przez handel zagraniczny. Dochód netto USA z ich działalności był również większy niż z handlu zagranicznego ${ }^{11}$. Dlatego ich wpływ na politykę gospodarczą stopniowo wzrastał.

Według teorii przewagi monopolistycznej Stephena Hymera ${ }^{12}$ firmy decydujące się na rozszerzenie działalności poza granice kraju macierzystego powinny posiadać cechy, które wyróżniają je na przyjmującym rynku: nowe produkty, przewagę technologiczną i finansową, nowoczesne sposoby zarządzania. Dominację zapewniał im również efekt skali. Te warunki spełniały wielkie przedsiębiorstwa amerykańskie, wykorzystujące supremację wynikającą ze skali produkcji, tworzące struktury oligopolu. Raymond Vernon, autor teorii cyklu życia produktu ${ }^{13}$, twierdził, że firmy amerykańskie miały większe szanse rozwoju nowych, bardziej innowacyjnych towarów ze względu na wysoki poziom dochodu społeczeństwa, które stać było na ich nabywanie. Wskazywał również na wysokie koszty pracy, które skłaniały przedsiębiorców do finansowania badań nad nowymi, bardziej oszczędnymi technologiami. Firmy pochodzące ze Stanów Zjednoczonych posiadały przewagę komparatywną dzięki wielkości rynku i dużym nakładom na badania i rozwój $j^{14}$.

Według teorii konkurencyjności międzynarodowej przedstawionej przez Michaela Portera na rynkach światowych dominują te grupy przedsiębiorstw, które dobrze prosperują również w kraju macierzystym. Dlatego zwracał on szczególną uwagę na otocze-

10 K. Kaiser, Transnational Relations as the Threat to the Democratic Process, „International Organization” 1971, Vol. 25, nr 3, s. 711.

11 E.R. Goodman, The Impact of the Multinational Enterprise upon Atlantic Community, [w:] The New Europe and the U.S. Partners or Rivals, red. G. Mally, Lexington 1974, s. 247, Lexington Books.

12 S. Hymer, International Operations of National Firms. A Study of Direct Foreign Investment, Cambridge 1976, passim, MIT Monographs in Economics, 14.

13 Według tej koncepcji w momencie spadku sprzedaży danego produktu na rodzimym rynku firmy dążą do jego umiędzynarodowienia, najpierw poprzez eksport, a w kolejnej fazie przenosząc jego produkcję do krajów trzecich. Gdy traci on swą unikalność - jest kopiowany przez innych producentów, firma stara się go udoskonalić bądź wprowadza na rynek zupełnie inny produkt. Zob. R. Vernon, International Investment and International Trade in the Product Cycle, "Quarterly Journal of Economics" 1966, Vol. 80, nr 2, s. 190-207.

14 Tamże, s. 194. 
nie polityczne, w którym firma funkcjonowała, na czynniki produkcji, strategię i sposób zarządzania przedsiębiorstwem, charakter popytu krajowego oraz siłę konkurencji ${ }^{15}$.

Przedstawione powyżej wybrane teorie ekonomiczne tłumaczyły przewagę korporacji amerykańskich, biorąc pod uwagę ich potencjał gospodarczy. Robert Gilpin, reprezentujący podejście państwowocentryczne, twierdził, że była ona wynikiem dominacji Stanów Zjednoczonych po II wojnie światowej. Zauważał także, że korporacje były produktem kultury, historii i systemu gospodarczego poszczególnych państw. W pracy US Power and the Multinational Corporation. The Political Economy of Foreign Direct Investment (Potęga Stanów Zjednoczonych i korporacje międzynarodowe. Ekonomia polityczna zagranicznych inwestycji bezpośrednich) zawarta jest neomerkantylistyczna koncepcja tłumaczenia współzależności oraz postrzeganie międzynarodowej polityki gospodarczej jako wzajemnej i dynamicznej interakcji $w$ stosunkach międzynarodowych $w$ procesie dażenia do osiagnięcia dobrobytu $i$ sity ${ }^{16}$. Autor twierdzil, że międzynarodowe stosunki gospodarcze mają charakter polityczny. Wysunął tezę, że współzależność gospodarek narodowych wytwarza ekonomiczną siłę, którą można określić jako potencjalną możliwość jednego kraju zaszkodzenia innemu poprzez zerwanie z nim relacji handlowych i finansowych. Twierdził, że ekspansja amerykańskich korporacji może być rozumiana wyłącznie w kontekście globalnego systemu politycznego ustanowionego po II wojnie światowej ${ }^{17}$. Autor udowadniał, że każdy system gospodarczy jest oparty na określonym porządku, więc jego natura nie może być zrozumiała bez kontekstu politycznego. Dlatego po zakończeniu II wojny światowej dominowała tendencja do zapewniania wolności inwestycji, a prymat międzynarodowych korporacji był odzwierciedleniem interesów politycznych i gospodarczych najsilniejszych aktorów (w systemie zachodnim - Stanów Zjednoczonych $)^{18}$.

\section{PRZYKŁADY WSPÓŁZALEŻNOŚCI PAŃSTW I KORPORACJI MIĘDZYNARODOWYCH}

W XXI wieku, wraz z postępującym procesem globalizacji, trudno jednoznacznie określić przynależność narodową wielkich korporacji działających na światowym rynku. Filie tych firm ulokowane w poszczególnych krajach są często tylko w niewielkim stopniu zależne od centrum, tworząc "globalne sieci”, podlegając fuzjom i przejęciom przez inne przedsiębiorstwa. W latach 60. i 70. XX wieku zdecydowanie łatwiej było utożsamić firmę z konkretnym państwem, przez co ich związki z krajami pochodzenia były

15 M.E. Porter, The Competitive Advantage of Nations, „Harvard Business Review” 1990, Vol. 68, nr 2, s. 73-91.

16 R. Gilpin, US Power and the Multinational Corporation. The Political Economy of Foreign Direct Investment, New York 1975, s. 86.

17 Tamże, s. 19, 38.

18 Tamże, s. 86. 
większe ${ }^{19}$. Dlatego teorie dotyczące tych firm formułowane w tamtym okresie za punkt odniesienia przyjmowały państwo narodowe, tłumacząc ich działania przez pryzmat pochodzenia $\mathrm{z}$ konkretnego kraju.

Jednak według Elliota Goodmana nie miała już wtedy zastosowania tradycyjna teoria handlu, mówiąca, że państwa ustalają wszystkie jego warunki. Międzynarodowe korporacje eksportowały kapitał, technologię i techniki zarządzania. Państwo narodowe miało być tylko punktem odniesienia - działając na forum międzynarodowych organizacji gospodarczych i zawierając umowy międzypaństwowe liberalizujące wymianę ${ }^{20}$. Z drugiej strony udowadniano, że przedsiębiorstwa pochodzące ze Stanów Zjednoczonych i Europy Zachodniej były powiązane z własnymi rządami przez „niewidzialne podanie ręki” (invisible handshake). Rządy państw zachodnich używały narzędzi politycznych, by stwarzać dogodne warunki na rynkach zagranicznych dla współpracujących z nimi firm, które w zamian działały w gospodarczym, a czasem politycznym interesie kraju pochodzenia ${ }^{21}$. Jack Berman twierdził, że zamiast szukania odpowiedzi na pytanie, czy rząd ma prawo ingerować w działalność korporacji, trzeba zastanowić się raczej, jakie ma możliwości, by to realizować.

Próby wyjaśnienia związków między rządami a międzynarodowymi korporacjami opierały się na jednym z dwóch założeń:

1) państwa współpracują z nimi, by realizować własne interesy i akceptują ich siłę;

2) występuje konflikt interesów: rządy (zarówno państw macierzystych, jak i przyjmujących zagraniczne firmy) starają się bronić przed rosnącymi wpływami tych korporacji ${ }^{22}$.

Oba te założenia można udowodnić na konkretnych przykładach, gdyż wzajemne oddziaływanie obu podmiotów może przynosić pozytywne i negatywne skutki. Niewątpliwa jest natomiast ich współzależność. Państwa posiadają zasoby atrakcyjne dla przedsiębiorstw: surowce, siłę roboczą czy dogodne położenie geograficzne. Dysponują również środkami prawnymi umożliwiającymi stwarzanie przyjaznego środowiska dla inwestorów, promowanie lub hamowanie swobodnej działalności gospodarczej. Mogą wpływać na postrzeganie zagranicznych firm przez opinię publiczną oraz biorą udział w kształtowaniu zasad działania gospodarki światowej na międzynarodowych forach. Wśród zasobów korporacji międzynarodowych, z których mogą korzystać państwa, można wymienić: kapital, technologię i wiedzę, możliwość tworzenia nowych miejsc pracy oraz dostęp do rynków zagranicznych. Potężnym narzędziem jest elastyczność ich działania: mogą wycofać się z danego kraju, co w przypadku wcześniejszej aktywności na dużą skalę może powodować problemy gospodarcze kraju przyjmującego, a przede wszystkim poważne skutki społeczne w postaci utraty miejsc pracy. Firmy

19 G. Jones, Nationality and Multinationals in Historical Perspective, [online] http://www.hbs.edu/ faculty/Publication\%20Files/06-052.pdf, 17 X 2013.

20 E.R. Goodman, The Impact of the Multinational..., s. 247.

21 R. Keohane, V.D. Ooms, The Multinational Enterprise and World Political Economy, „International Organization" 1975, Vol. 26, nr 1, s. 120.

22 K. Rodman, Sanctions Beyond Borders. Multinational Corporations and US Economic Statecraft, Lanham 2001, s. 6. 
mogą stosować również nacisk polityczny, przekonując do swoich racji polityków, lobbystów, dziennikarzy, koalicje biznesowe czy ekspertów doradzających rządom ${ }^{23}$.

Susan Strange zauważyła, że korporacje i rządy działają w dwóch różnych wymiarach: rząd działa w interesie państwa narodowego i dąży do utrzymania władzy; celem międzynarodowych firm jest natomiast maksymalizacja zysków. Dlatego ich interesy bywają rozbieżne, ale także często mogą współpracować dla obopólnych korzyści. Każdy z aktorów posiada różne narzędzia oddziaływania i używa ich w zależności od swej siły i aktualnych okoliczności. Dlatego dyplomacja gospodarcza jest prowadzona zarówno przez urzędników państwowych, jak i przedstawicieli korporacjii ${ }^{24}$. Zgodnie z koncepcją władzy strukturalnej autorstwa Strange ma ona cztery wymiary: bezpieczeństwa, produkcji, finansów i wiedzy. Zdolność państwa do panowania nad tymi strukturami kształtuje jego władzę relacyjną, czyli potencjał do realizacji celów na arenie międzynarodowej, wpływu na podmioty zewnętrzne i narzucanie globalnych reguł, także poprzez organizacje międzynarodowe. $\mathrm{Z}$ tych powodów niezależność korporacji międzynarodowych stanowiła duże wyzwanie dla państw narodowych ${ }^{25}$.

Do bardziej radykalnych wniosków doszedł Harry Magdoff, pracownik Departamentu Handlu w administracji Franklina D. Roosevelta i wpływowy komentator lewicowego, amerykańskiego miesięcznika „Monthly Review”. W pracy na temat czynnika gospodarczego w polityce zagranicznej Stanów Zjednoczonych (The Age of Imperialism. The Economics of U.S. Foreign Policy) stwierdził, że korporacje międzynarodowe były najważniejszymi instrumentami amerykańskiego imperializmu. Budowały one sieci zależności gospodarczych, a konieczność ochrony ich działalności prowadziła do zakładania amerykańskich baz militarnych w różnych częściach świata. Sytuacja taka była szczególnie niekorzystna dla bogatych w surowce, rozwijających się krajów. Według Magdoffa były one nieuczciwie eksploatowane, co umacniało więzy korporacji z rządem $^{26}$. W związku z tego typu oskarżeniami władze korporacji doświadczały tzw. dylematu lojalności. Z jednej strony w krajach je przyjmujących chciały udowodnić, że nie stanowiły narzędzia amerykańskiej polityki i ich działalność korzystnie wpływała na gospodarkę. $\mathrm{Z}$ drugiej strony były uzależnione od działań własnego rządu, którego praw musiały przestrzegać $c^{27}$.

Według Jacka Behrmana, aby uniknąć takiej sytuacji, konieczne były konkretne porozumienia międzyrządowe. Jednak zarówno korporacje, jak i rządy nie angażowały się wystarczająco w tę kwestię, nie mogąc dojść do porozumienia. Problematyka zasad funkcjonowania korporacji mogła powodować napięcia międzyrządowe ze względu na

23 A. Jarczewska-Romaniuk, Relacje polityki i ekonomii..., s. 44-47.

24 S. Strange, The Retreat of the State. The Diffusion of Power in the World Economy, New York 1996, s. 197, Cambridge Studies in International Relations, 49.

25 L. Panitch, M. Konings, Demystifying Imperial Finance, [w:] American Empire and the Political Economy of Global Finance, red. L. Panitch, M. Konings, New York 2008, s. 6, International political economy series (Palgrave Macmillan (Firm)).

26 H. Magdoff, The Age of Imperialism. The Economics of U.S. Foreign Policy, New York 1969, passim.

27 R. Vernon, Sovereignty at Bay Ten Years After, „International Organization” 1981, Vol. 35, nr 3, s. 517 -529 . 
różne interesy poszczególnych państw. Od 1971 roku na forum Organizacji Współpracy Gospodarczej i Rozwoju (Organisation for Economic Co-operation and Development - OECD) podjęto wysiłki w celu uzgodnienia zasad lepszej kontroli ich poczynań, a także gwarancji bezpiecznej działalności. Zaowocowało to kilkoma deklaracjami, między innymi zobowiązaniami do traktowania przedsiębiorstw zagranicznych tak samo jak firm rodzimych, jednak kraje uprzemysłowione zawierały raczej umowy bilateralne, np. na temat unikania podwójnego opodatkowania, dzieląc zyski z podatków od firm ${ }^{28}$.

Badacze analizujący zagraniczną politykę gospodarczą Stanów Zjednoczonych, opierając się na podejściu państwowocentrycznym, określali ten kraj jako „słaby”, biorąc pod uwagę duży stopień decentralizacji władzy i stosunkowo niewielkie uprawnienia urzędników państwowych, postrzeganych jako niezależni uczestnicy procesu politycznego ${ }^{29}$. Rozproszone centra decyzyjne i instytucje biurokratyczne, ścieranie się sprzecznych interesów w Kongresie sprawiało, że korporacje międzynarodowe mogły działać bardziej niezależnie od rządu (w porównaniu np. z Japonią) i bronić się poprzez lobbing przed niekorzystnymi dla siebie projektami ustaw.

Jednak zorganizowanie współpracy przedsiębiorstw międzynarodowych $\mathrm{w}$ tym celu było utrudnione, ze względu na rozbieżności interesów różnych branż i rywalizacji w ramach tych samych gałęzi przemysłu lub usług. Mimo to w obliczu poważnego zagrożenia firmy były zdolne do organizacji wspólnej akcji. Jako przykład może służyć poddany pod obrady Kongresu 28 września 1972 roku projekt ustawy Hartke-Burke (Foreign Trade and Investment Act) ${ }^{30}$. Miał on na celu ograniczenie importu i wprowadzenie ulg podatkowych dla niektórych firm eksportowych. Zapisano w nim również propozycję zacieśnienia kontroli nad wszystkimi BIZ i ścisłą regulację transferu amerykańskiej technologii przez firmy z USA działające za granicą. Chciano też zwiększyć podatki od operacji finansowych dokonywanych poza Stanami Zjednoczonymi oraz wprowadzić kontrolę i ograniczenie odpływu amerykańskiego kapitału. Proponowano również zniesienie ulg podatkowych od zagranicznych zysków. Protesty związków zawodowych przeciw przenoszeniu produkcji za granicę spowodowały, że projekt ustawy zawierał klauzulę o regulacjach działalności korporacji międzynarodowych. Stwierdzono, że to one były odpowiedzialne za wzrost konkurencyjności towarów europejskich, co hamowało wzrost gospodarczy w USA, przyczyniało się do spadku poziomu życia i wzrostu bezrobocia ${ }^{31}$.

Prezydent Richard Nixon sprzeciwiał się przyjęciu przez Kongres tej ustawy. Był też sceptyczny wobec projektu „GATT dla Inwestycji”, mającego koordynować kontrolę

28 J.N. Behrman, National Interests and the Multinational Enterprise..., s. 176-185.

29 G.J. Ikenberry, D.A. Lake, M. Mastanduno, Introduction. Approaches to Explaining American Foreign Economic Policy, „International Organization” 1988, Vol. 42, nr 1, s. 9-10.

30 Ustawę zgłosili James A. Burke - członek Izby Reprezentantów z Massachusetts, i Vance Hartke senator z Indiany (obaj byli członkami Partii Demokratycznej).

31 Policy Aspects of Foreign Investment by US Multinational Corporations, [w:] The Multinational Corporation. Studies on US Foreign Investment, Vol. 1, Office of International Investments, Washington 1972, s. 1-5, United States Department of Commerce Publication. 
państw OECD nad przepływem kapitału ${ }^{32}$. Opinia prezydenta, a także zorganizowany lobbing amerykańskiego biznesu (Amerykańskiej Izby Handlowej, Narodowej Rady Handlu Zagranicznego) w Kongresie doprowadziły do odrzucenia ustawy.

Oprócz bezpośredniego lobbingu w Kongresie korporacje mogły również poprzez akcje propagandowe kształtować opinię publiczną, która z kolei wpływała na rząd. Korzystały z tych możliwości państwa trzecie, w których lokowane były inwestycje z USA. Od początku lat 60. rząd Kanady naciskał na korporacje amerykańskie, by przekonały władze swojego kraju do liberalizacji handlu samochodami. Działania te odniosły skutek - porozumienie w tej sprawie zawarto w $1965 \mathrm{roku}^{33}$.

Kolejne administracje Stanów Zjednoczonych uważały, że ekspansja korporacji z USA jest $w$ ich interesie. Najwięcej inwestycji firm amerykańskich płynęło do państw Europy Zachodniej. W 1950 roku znajdowało się tam tylko ok. 15\% ich BIZ (1,7 mld USD), do 1970 roku - już 32\% (24,5 mld USD). Związany z nimi dochód dla budżetu przekraczał 2 mld USD ${ }^{34}$. Dominowały wielkie firmy, także z sektora bankowości. W 1950 roku najwięcej inwestycji płynęło do Wielkiej Brytanii, Francji i RFN. W 1970 roku RFN wyprzedziło w tym rankingu Francję ${ }^{35}$.

Oprócz bezpośrednich korzyści finansowych przewidywano, że siła korporacji pomoże w utrzymaniu dominacji na rynkach światowych wobec konkurencji z EWG i Japonii. Jednocześnie inwestycje amerykańskie przyczyniały się do rozwoju gospodarek państw sojuszniczych, wzmacniając blok antykomunistyczny. Rząd amerykański wspierał BIZ, widząc w nich narzędzie światowej liberalizacji handlu oraz instrument otwarcia nowych rynków dla produkcji USA. Z przesłuchań senackiej podkomisji zajmującej się zagadnieniem rozwoju przedsiębiorstw międzynarodowych wyłania się pozytywny obraz ich działalności. Doceniono wagę korporacji w polityce zagranicznej ze względu na to, że udzielały informacji o sytuacji politycznej i gospodarczej kraju, w którym działały. Czasem pomagały także we wprowadzaniu polityki promowanej przez amerykańską administrację, jeśli leżało to również w ich interesie ${ }^{36}$. Prezydent Nixon spotykał się wielokrotnie z szefami korporacji, zapewniając, że rząd Stanów Zjednoczonych popiera ich rozwój i docenia pozytywny wpływ na amerykańską gospodarkę ${ }^{37}$.

Analizując ingerencję państwa w działalność korporacji międzynarodowych w czasie zimnej wojny, należy zwrócić uwagę na problem przestrzegania ograniczeń relacji gospodarczych. Od 1949 roku obowiązywała ustawa Export Control Act, obligująca

32 R.F. Janssen, Multinationals Face Disorderly Struggle Over Foreign Controls, Conference Finds, „The Wall Street Journal” 1973, 8 I. Zob. także: W. Diebold Jr., U.S. Trade Policy. The New Political Dimension, „Foreign Affairs” 1974, Vol. 52, nr 3, s. 476-479.

33 A. Rugman, Multinationals and Canada-United States Free Trade, Columbia 1990, s. 23-24, Critical Issues Facing the Multinational Enterprise.

34 C.J. Elia, Europeans, Japanese Find the Time is Ripe to Acquire US Firms, „Wall Street Journal” 1973, $22 \mathrm{IV}$.

35 M. Nolan, The Transatlantic Century. Europe and America, 1890-2010, Cambridge 2012, s. 197-198, New Approaches to European History, 46.

36 J.E. Spero, The Politics of International Economic Relations, New York 1999, s. 124.

37 J. Gannon, High Level Friends, „Wall Street Journal” 1972, 13 I. 
prezydenta do ograniczania eksportu do krajów bloku komunistycznego. Jednocześnie działał program koordynacji polityki z sojusznikami USA dla utrzymania embarga na dobra strategiczne dla ZSRR. W jego ramach utworzono dwa komitety: Ministerialną Grupę Konsultacyjną (Ministerial Consultative Group - MCG) i Komitet Koordynacyjny (Coordinating Committee for Multilateral Export Controls - COCOM). Zadaniem MCG było wytyczanie celów politycznych, COCOM ustalał listę towarów objętych embargiem ${ }^{38}$. Administracja wywierała nacisk na oddziały korporacji afiliowanych w Stanach Zjednoczonych, by stosowały się do tego prawa. Przykładem konfliktu z tym związanego, który spowodował napięcia międzyrządowe, był przypadek, kiedy filia francuska przedsiębiorstwa amerykańskiego Fruehauf podpisała kontrakt na dostawę sprzętu do produkcji ciężarówek przeznaczonych na eksport do Chin. Rząd USA polecił zerwać kontrakt, ale sąd francuski orzekł, że filia francuska nie podlega kontroli eksportu według prawa amerykańskiego i nakazał go wypełnić3 ${ }^{39}$. Z kolei rząd kanadyjski udzielił poparcia firmie Litton, która planowała sprzedaż mebli biurowych na Kubę. Odpowiadając na sprzeciw rządu USA, kanadyjski minister przemysłu oświadczył, że był to przykład „kolonializmu handlowego USA” i próba ingerencji w sprawy wewnętrzne sąsiedniego państwa ${ }^{40}$. By zapobiec podobnym przypadkom, doszło do uchwalenia ustawy mówiącej, że firmy działające na terenie Kanady nie miały prawa wykonywać zagranicznych dyrektyw, które mogły być szkodliwe dla gospodarki tego państwa. Rząd USA ustąpił i uchylił zakaz, lecz był to przypadek wyjątkowy. Przeważnie Waszyngton starał się egzekwować swoje wymagania, a firmy działające za granicą nie angażowały się w „zakazany” biznes ${ }^{41}$.

W latach 70. XX wieku, w czasie odprężenia w stosunkach z ZSRR, rząd Stanów Zjednoczonych zachęcał nowo powstałe kraje postkolonialne do związania przyszłości z obozem państw kapitalistycznych. W 1971 roku powstała wspierana przez rząd instytucja Overseas Private Investment Corporation, mająca promować rozwój poprzez ułatwienia działalności dla inwestorów. W jej prace byli zaangażowani prywatni przedsiębiorcy, którym administracja ułatwiała inwestowanie w ważnych strategicznie regionach, dając gwarancje polityczne ${ }^{42}$.

Wiele korporacji utrzymywało kontakty z ambasadami amerykańskimi w krajach, w których działały. Placówki te były przede wszystkim źródłem informacji. W przypadku, gdy uznawano, że problemy firm w danym kraju miały wpływ na szeroko pojęte interesy USA, udzielały im one wsparcia dyplomatycznego. Nie istniało bowiem prawo międzynarodowe regulujące ich działalność, dlatego nie mogły same bronić się przed dyskryminacją. Przedstawiciele korporacji amerykańskich twierdzili na przykład, że

38 F.D. Holzman, R. Legvold, The Economics and Politics of East-West Relations, „International Organization" 1975, Vol. 29, nr 1, s. 277-283.

39 R.F. Kuisel, Seducing the French. The Dilemma of Americanization, Berkeley 1993, s. 164.

40 J.N. Behrman, National Interests and the Multinational Enterprise..., s. 112.

41 Tamże, s. 113.

42 Więcej informacji na temat Overseas Private Investment Corporation zob. http://www.opic.gov/ who-we-are/overview, 21 I 2014. 
rządy Francji i Wielkiej Brytanii stwarzają gorsze warunki działalności dla firm, które miały główne oddziały w innych krajach EWG. Oficjalnie ani ambasady, ani Departament Stanu nie podjęły działań, by temu zapobiegać, lecz dyplomaci wspominali nieformalnie o tym problemie.

Administracja Stanów Zjednoczonych niechętnie angażowała się bezpośrednio $\mathrm{w}$ dysputy $\mathrm{z}$ władzami innych krajów, gdyż przenoszenie rozbieżności na poziom międzyrządowy mogło niekorzystnie wpływać na relacje polityczne. Nadmierna presja mogła także zaszkodzić interesom firm. Należy również brać pod uwagę, że były one kojarzone ze Stanami Zjednoczonymi, więc metody ich działania wpływały na wizerunek tego kraju, a w konsekwencji także na relacje międzynarodowe, zarówno na poziomie rządów, jak i społeczeństw.

Poza tym w przypadku USA występowała dodatkowa trudność: wiele potężnych korporacji z tego kraju często konkurowało w jednej branży. Kiedy ich interesy były rozbieżne, trudno było wesprzeć jedną z nich, nie narażając się na oskarżenia o stronniczość. Władze amerykańskie musiały prowadzić wyważoną politykę. Jako przykład może służyć przypadek z 1968 roku, kiedy rząd Peru zdecydował się na nacjonalizację majątku należącego do filii amerykańskiej korporacji Exxon. W takich okolicznościach rządy Stanów Zjednoczonych z reguły decydowały się na zdecydowane działania, wchodząc w konflikt międzypaństwowy w interesie przedsiębiorstwa ${ }^{43}$. Jednak inne firmy funkcjonujące w tym kraju zwróciły się z prośbą do administracji, by nie stawiała sprawy na ostrzu noża, gdyż mogło to spowodować dla nich znaczne straty. Sugerowano, by starać się raczej o wypłatę jak największych rekompensat. Było to również rozwiązanie wygodniejsze dla rządu USA, gdyż postawa wobec Peru była ważnym elementem polityki względem regionu. Także Lima dążyła do polubownego załatwienia sprawy, gdyż starała się o pożyczki ze Stanów Zjednoczonych i od Międzynarodowego Funduszu Walutowego. W związku z tym w 1973 roku udało się wynegocjować korzystne porozumienie ${ }^{44}$.

Również korporacje niechętnie uciekały się do pomocy rządu, starając się unikać jego ingerencji i zobowiązań do działań, które mogłyby być niekorzystne dla kraju przyjmującego ${ }^{45}$. Było to zrozumiałe tym bardziej, że rządy, zarówno w kraju macierzystym, jak i przyjmującym, nie ufały korporacjom, ze względu na niemożność sprawowania kontroli nad ich poczynaniami. Podczas międzynarodowej konferencji energetycznej w Waszyngtonie w lutym 1974 roku RFN zgłosiła inicjatywę, by państwa dokonały

43 Wystarczy przypomnieć wsparcie CIA dla puczystów w Gwatemali, którzy w maju 1954 roku obalili lewicowego prezydenta Jacoba Arbenza Guzmána. Wcześniej zapowiadał on reformę rolną, która oznaczałaby m.in. przejęcie gruntów należących do United Fruit Company (więcej na ten temat zob. J. Ranelagh, The Agency. The Rise and Decline of the CIA, New York 1987, s. 264-267). Drugim przykładem były działania wobec komunistycznej Kuby, na którą rząd USA nałożył embargo gospodarcze po serii nacjonalizacji majątku amerykańskich firm.

44 R. Vernon, Storm over the Multinationals. The Real Issue, Cambridge, Mass. 1977, s. 130-131.

45 Carl Gerstader, szef korporacji Dow Chemicals, marzył podobno o kupieniu na potrzeby swojej firmy bezludnej wyspy, która nie należałaby do żadnego rządu. Zob. J.S. Nye, Multinationals. The Game and the Rules..., s. 173. 
wspólnej analizy polityki cenowej, dochodów i opodatkowania międzynarodowych korporacji naftowych. Władze były zaniepokojone tym, że w owej dziedzinie energetyki miały bardzo małą kontrolę nad tymi przedsiębiorstwami, które, nie zważając na kryzys, nie chciały dopuścić do obniżenia zysków i podwyższały ceny. Rząd niemiecki zauważył, że bez współpracy międzynarodowej trudno będzie wpłynąć na korporacje, a tym samym w pełni kształtować politykę gospodarczą ${ }^{46}$. Wszelkie próby ustalenia wspólnych reguł nie przyniosły jednak konkretnych rezultatów ${ }^{47}$.

W czasie kryzysu energetycznego rządy przekonały się, do jakiego stopnia były uzależnione w tej dziedzinie od wielkich przedsiębiorstw. Chodziło o to, by firmy nie mogły zawierać niezależnych układów z producentami. Problem ten dotyczył szczególnie państw europejskich - niektóre kraje eksportujące ropę wolały zawierać umowy na jej dostawę z międzynarodowymi korporacjami niż z rządami. Natomiast kontrakty z rządem USA były dla nich z reguły bardziej atrakcyjne. Administracja amerykańska nie miała jednak kontroli nad ulokowanymi w Stanach Zjednoczonych przedsiębiorstwami. Jeszcze przed kryzysem energetycznym, latem 1973 roku, gdy na wielu stacjach benzynowych w USA ustawiały się kolejki spowodowane brakiem towaru ${ }^{48}$, w Senacie dyskutowano, czy nie była to celowa gra przedsiębiorstw w celu podwyższenia cen ${ }^{49}$.

Pojawiało się pytanie, czy firmy te nie ograniczają kontroli państwa nad gospodarką. Charles Kindleberger zauważał, że ich bezprecedensowa ekspansja powodowała problemy polityczne, gdyż próbowały wpływać na rządy, by ustanawiały prawa umożliwiające im swobodne działanie. Dlatego stanowiły wyzwanie dla państw narodowych. W Stanach Zjednoczonych wpływy jednej korporacji mogły być równoważone przez inną, miały one także wspólny cel: popierały liberalną politykę, by ich inwestycje zagraniczne nie stały się przedmiotem działań odwetowych rządów państw je przyjmujących. Jednak przedstawiciele międzynarodowych korporacji mogli również wpływać na politykę krajów, w których te inwestowały, łącznie ze zmianą nieprzyjaznego rządu, przede wszystkim poprzez finansowanie kampanii wyborczych ${ }^{50}$.

Wielkie przedsiębiorstwa, niechętne dostosowywaniu się do wymagań jednego rządu, miały możliwość przenoszenia produkcji tam, gdzie mogły uzyskać korzystniejsze warunki. W ich interesie było więc, by rola rządów ograniczała się do redukowania kosztów transakcji: zawierania dwu- lub wielostronnych porozumień

46 R. Gilpin, US Power and the Multinational Corporation..., s. 242.

47 Więcej na ten temat zob. R. Keohane, V.D. Ooms, The Multinational Firm and International Regulations, [w:] World Politics and International Economics, red. C.F. Bergsten, L.B. Krause, Washington 1975, s. 196.

48 E. Cowan, The Gasoline Shortage. Real or Contrived?, „New York Times” 1973, 8 VI. Podobne podejrzenia pojawiły się w prasie w grudniu 1973 roku. Zob. D.E. Kneelands, Energy. Many Skeptical on Reasons of Crisis, „New York Times” 1973, 23 XII.

49 Congressional Record. Proceeding and Debates of the First Session of the 93rd Congress, Vol. 119, cz. 33, posiedzenieSenatuz 19XII 1973, [online] http://www.archive.org/stream/congressionalrec119qunit/ congressionalrec119qunit_djvu.txt, 2 III 2013.

50 D.M. Ray, Corporations and American Foreign Relations, "The Annals of the American Academy of Political and Social Science" 1972, Vol. 403, s. 80-92. 
(np. w celu uniknięcia podwójnego opodatkowania), umów o dobrych praktykach lub stwarzających korzystne warunki w gospodarce światowej: dotyczących systemu monetarnego, handlu itp.

Generalnie rządom poszczególnych państw zależało na przyciąganiu inwestycji amerykańskich przedsiębiorstw międzynarodowych. Zapewniały one transfer najnowocześniejszej technologii, kapitału, przekazywały wzorce efektywnego zarządzania, zapewniały profesjonalne szkolenia, usprawnienie dystrybucji międzynarodowej oraz nowe miejsca pracy. Zwiększały się również obroty handlowe między poszczególnymi państwami, przyjmowano nowe międzynarodowe regulacje i wspólne standardy.

Korzyści z działalności przedsiębiorstw międzynarodowych odnosił również rząd Stanów Zjednoczonych. Obok dochodów dla budżetu i znaczenia politycznego korporacje miały pozytywny wpływ na bezpieczeństwo USA. Dominowały bowiem w sektorach wysokiej technologii, prowadziły badania przyczyniające się do postępu także w sektorze obronności, gdy przyjmowały zamówienia rządowe. Czasem były jednak oskarżane o sprzedawanie produktów o znaczeniu strategicznym. Jednak w 1971 roku Komisja Ceł wydała raport, z którego wynikało, że w większości przypadków korzyści z wymiany ze Wschodem przeważały nad stratami: firmy nie eksportowały tam najbardziej zaawansowanej technologii. Stwierdzono też, że jej transfer do krajów sojuszniczych był konieczny, gdyż wobec prób jego ograniczenia firmy amerykańskie mogły spotkać się z działaniami odwetowymi.

Zdarzało się także, że firmy realizowały własne interesy wbrew polityce rządu, $\mathrm{np}$. angażując się $\mathrm{w}$ niekonsultowane $\mathrm{z}$ Waszyngtonem negocjacje $\mathrm{z}$ władzami krajów-gospodarzy. Przedstawiciele koncernu naftowego Gulf Oil w Angoli ustalali warunki działalności bezpośrednio z komunistycznym rządem, choć Waszyngton nakazał zaprzestanie odwiertów w tym kraju. Kolejnym przypadkiem samowolnej, szkodzącej wizerunkowi kraju macierzystego działalności firm były przykłady korupcji. Najgłośniejszą sprawą była afera Lockheed, firmy lotniczej, która płaciła rządom państw obcych za zawieranie lukratywnych kontraktów ${ }^{51}$.

Wzrost roli korporacji w gospodarce światowej miał duży wpływ na stosunki międzynarodowe. Wytwarzały się współzależności w relacjach między państwami, co często przyczyniało się do zwiększenia skłonności do współpracy, ale także powodowało konflikty na poziomie międzyrządowym, nawet między sojusznikami. Firmy międzynarodowe były więc ważnym źródłem siły państw, ale niekiedy również obciążeniem.

\section{INWESTYCJE AMERYKAŃSKICH PRZEDSIĘBIORSTW W EUROPIE}

Ekspansja korporacji międzynarodowych i instytucji finansowych do Europy zmieniała gospodarkę zachodu Starego Kontynentu. Wzrastał sektor prywatny, następowały racjonalizacja i modernizacja technologiczna, rozwój transportu i komunikacji, zmianom

51 E.B. Staats, U.S. Foreign Relations and Multinational Corporations. What's the Connection?, Report to the Congress, 23 VIII 1978, [online] http://www.gao.gov/assets/130/123830.pdf, 10 X 2013. 
ulegał styl zarządzania przedsiębiorstwami. Już w latach 50. XX wieku uruchomiono US Technical Assistance Program. W jego ramach biznesmeni amerykańscy przyjeżdżali do Europy, by doradzać rządom i przedsiębiorcom, przy okazji negocjując korzystne warunki dla własnych inwestycji. Finansowano również wyjazdy szkoleniowe Europejczyków do Stanów Zjednoczonych ${ }^{52}$.

Wspierając powojenną odbudowę Europy w ramach planu Marshalla, Amerykanie oczekiwali, że będą tam imitowane ich wzorce rozwojowe skierowane na wzrost produkcyjności. Teoria modernizacji, która od lat 50 . XX wieku była popularna w USA, zakładała, że wszystkie kraje przyjmą ostatecznie polityczny i gospodarczy model amerykański. Według jej założeń społeczeństwa będą charakteryzowały określone cechy: dążenie do sukcesu, racjonalność i niechęć do korupcji. Wykształcą się dzięki temu stabilne instytucje polityczne i prawne, a w sferze gospodarczej ugruntuje się swoboda działania dla biznesu ${ }^{53}$. Walt Rostow w pracy The Stages of Economic Growth. A Non-Communist Manifesto (Etapy wzrostu gospodarczego. Manifest niekomunistyczny) stwierdzit, że społeczeństwa rozwijają się w sposób ewolucyjny, przechodzą przez te same etapy, od ekonomii tradycyjnej do fazy wysokiej konsumpcji. Rozwój ten można przyspieszyć poprzez pomoc i inwestycje zagraniczne oraz reformy wewnętrzne $e^{54}$.

Mimo ewidentnych wpływów wzorców zza oceanu na działalność firm nie można mówić o całkowitej „amerykanizacji” europejskiego systemu gospodarczego. Oprócz najbardziej oczywistego wyróżnika - tworzenia europejskich organizacji integracyjnych, inne były tam stosunki pracy. Charakterystyczny był korporacjonizm związków zawodowych, które w Europie skupiały pracodawców i pracowników oraz miały silniejsze niż w USA powiązania ze strukturami partyjnymi. Należy również zauważyć, że nie było w sposób równie restrykcyjny jak w Stanach Zjednoczonych przestrzegane prawo antymonopolowe. W określonych przypadkach w Europie Zachodniej dopuszczano funkcjonowanie karteli, także po to, by europejskie firmy miały większe szanse w konkurowaniu z amerykańskimi. Na Starym Kontynencie rządy często przejmowaty kontrolę nad ważnymi przemysłami i bankami emisyjnymi, występowały nawet elementy planowania w gospodarce, z pewnością bardziej rozbudowany był też system opieki społecznej i ubezpieczeń zdrowotnych. Poza tym w Stanach Zjednoczonych firmy bardziej agresywnie konkurowały ze sobą o udział w rynku, podczas gdy w Europie wyraźna była tendencja do negocjacji w sprawie jego podziału ${ }^{55}$.

W latach 70. XX wieku większość amerykańskich BIZ była skoncentrowana w krajach uprzemysłowionych: 37\% w Europie Zachodniej, 23\% w Kanadzie i 3\% w Japonii ${ }^{56}$. Najwięcej z nich było ulokowanych w przemyśle chemicznym, elektronicznym i w transporcie. Także banki z USA tworzyły swoje filie w tych krajach.

52 M. Nolan, The Transatlantic Century..., s. 194-195.

53 P.J. Akard, Corporate Mobilization and Political Power. The Transformation of U.S. Economic Policy in the 1970s, „American Sociological Review” 1992, Vol. 57, nr 5, s. 608-609.

54 W. Rostow, The Stages of Economic Growth. A Non-Communist Manifesto, Cambridge 1960, passim.

55 Tamże, s. 198-201.

56 J.E. Spero, The Politics of International..., s. 106. 
Rządy europejskie miały bardzo ambiwalentny stosunek do amerykańskich inwestycji, jak określił to Behrman: love-hate syndrom. Zdawały sobie sprawę, że korzyści z nich były niebagatelne. Oprócz doraźnych zysków Europejczycy postrzegali je jako impuls do własnego rozwoju. Po stworzeniu unii celnej przez kraje EWG w 1968 roku, przemysły poszczególnych krajów europejskich potrzebowały kapitału i technologii, by sprostać konkurencji z innych państw członkowskich. Chcąc zmniejszać nierówności między regionami, rządy zachęcały Amerykanów do lokowania inwestycji na obszarach mniej uprzemysłowionych lub takich, w których występowało największe bezrobocie.

Mimo tych pozytywnych aspektów w krajach Europy Zachodniej artykułowano wiele obaw związanych z amerykańską ekspansją gospodarczą. Problemy pojawiały się, gdy korporacje te zaczęły dominować na rynku, zagrażając miejscowym małym przedsiębiorstwom. Często Amerykanie wprowadzali nowe, atrakcyjniejsze lub tańsze produkty, dysponowali lepszą technologią i osiągali większą wydajność, co zmuszało europejskie firmy do obniżania cen i modernizacji, na co nie wszystkie mogły sobie pozwolićs7.

Wśród obaw związanych z obecnością na rynkach firm zza oceanu należy wymienić także strach przed uzależnieniem się przemysłu od amerykańskich inwestycji. Zjawisko przejmowania europejskich firm często określano w prasie mianem gospodarczej kolonizacji ${ }^{58}$. Ogromne inwestycje amerykańskie spowodowały, że spora część sektorów przemysłowych w krajach europejskich znalazła się pod kontrolą firm z USA. Filie przedsiębiorstw amerykańskich kontrolowały np. $75 \%$ europejskiego rynku komputerowego, produkowały 50\% sprzętu telekomunikacyjnego we Francji, posiadały 1/3 niemieckich rafinerii naftowych i zatrudniały $6 \%$ brytyjskiej siły roboczej. Występował również tzw. „drenaż mózgów” - przejmowanie wysoko wykwalifikowanej kadry, która masowo emigrowała do Stanów Zjednoczonych" ${ }^{59}$.

W tygodniku „Der Stern” podano na przykład, że 90\% produkcji komputerów i 40\% przemysłu samochodowego w RFN znajdowało się w rękach firm pochodzących z USA. Konkludowano, że nierówna sita graczy czyni grę nierówna, a amerykańskie przedsiębiorstwa przeważnie były w Europie liderami w swoim sektorze ${ }^{60}$. Miały także o ok. 50\% większe zyski niż firmy europejskie, inwestowały więcej w krajach przyjmujących i stanowiły potężną konkurencję na rynkach zewnętrznych ${ }^{61}$.

Niepokój Europejczyków wzbudzał też fakt, że amerykańskie korporacje intensyfikowały aktywność w przemysłach o strategicznym znaczeniu dla gospodarek, szczególnie tych opartych na nowych technologiach (np. przemyśle samochodowym czy

\section{J.N. Behrman, National Interests and the Multinational Enterprise..., s. 19-21.}

58 E.R. Goodman, The Fate of the Atlantic Community, New York 1975, s. 451, Praeger Special Studies in International Politics and Government.

59 P. Matera, Uwarunkowania ekonomiczne polityki Stanów Zjednoczonych wobec Europy Zachodniej za prezydentury Richarda M. Nixona (1969-1974), Łódź 2012, s. 93.

60 Przyznawano przy tym, że mimo to nie zawsze zajmowały pierwszą pozycję, gdyż np. Volkswagen był chętniej kupowanym samochodem niż Ford. Zob. J.N. Behrman, National Interests and the Multinational Enterprise..., s. 39. 
przetwórstwie ropy naftowej). Amerykanie mogli przejąć kontrolę nad tymi sektorami, które byłyby zależne od danej korporacji, co ograniczało możliwości działania rządu. Biorąc pod uwagę dążenie administracji USA do wpływu na działalność przedsiębiorstw za granicą, mówiono nawet o zagrożeniach dla suwerenności gospodarczej. Europejczycy stali na stanowisku, że zagraniczne inwestycje w każdy przemysł były z zasady pozytywne, jednak nie należało przekraczać pewnego pułapu. W RFN określono, że nie mogą one być większe niż $50 \%$ wartości danego sektora ${ }^{62}$. Dlatego rząd zachodnioniemiecki nieoficjalnie i „przyjacielsko” ostrzegał amerykańskie firmy naftowe, by nie spieszyły się z wejściem na ich rynek.

Z powyższym problemem łączyło się poczucie powiększania się tzw. luki technologicznej. Na ten temat wypowiadali się publicznie politycy, twierdząc, że poszczególne państwa europejskie nie mogą być tylko importerami technologii z USA, gdyż zwiększa to ich uzależnienie od firm z tego kraju. Przedsiębiorstwa europejskie, by utrzymać konkurencyjność, były czasem zmuszone do fuzji z amerykańskimi i w ten sposób korzystania z najnowocześniejszych technologii. Postulowano większe nakłady państw na badania naukowe, by wypracować oryginalne, rodzime rozwiązania. W latach 60 . w Stanach Zjednoczonych wydawano więcej na badania i rozwój niż łącznie w krajach europejskich i w Kanadzie. Należy przy tym pamiętać, że europejskie gospodarki korzystały z przepływu amerykańskiej technologii, a instytuty badawcze niektórych firm były organizowane także w krajach je przyjmujących ${ }^{63}$.

Znaczny udział przedsiębiorstw amerykańskich w produkcji mógł też powodować zaburzenie planów gospodarczych rządów. W krajach europejskich społeczeństwa obarczały rządy wielką (w porównaniu ze Stanami Zjednoczonymi) odpowiedzialnością za wzrost gospodarczy. Dlatego decydenci mieli tendencję do regulacji rynku w przypadku zagrożenia destabilizacją. Często godziło to w plany amerykańskich korporacji, przyzwyczajonych do innej filozofii działania, zgodnie z maksymą ,jak najmniej rządu w gospodarce". Zupełnie obca była im też idea planowania (realizowana np. we Francji) ${ }^{64}$. W Europie utrzymywano bliskie kontakty między rządem a biznesem, w celu ustalenia optymalnej strategii dla gospodarki narodowej, co nie było praktykowane w USA.

Istniały także obawy dotyczące przenoszenia na grunt europejski amerykańskich modelów zachowań konkurencyjnych, zwyczajów związanych np. z warunkami i z kulturą pracy czy komunikacją. Francuscy biznesmeni uważali, że to amerykańskie przedsiębiorstwa były odpowiedzialne za wojny cenowe i nieuczciwe promocje, pracownicy skarżyli się, że nie brały one pod uwagę społecznej odpowiedzialności biznesu. Pojawiały się też głosy, że poprzez nastawienie wyłącznie na zysk Amerykanie mogli zaszczepić w Europejczykach bezrefleksyjny materializm. Obawiano się również zwiększającej się popularności amerykańskiej kultury masowej ${ }^{65}$.

62 Tamże, s. 40.

63 Tamże, s. 55-59.

64 Więcej na temat planowania gospodarczego w Europie Zachodniej zob. J. Kaliński, Zarys historii gospodarczej XIX i XX w., Warszawa 2000, s. 245-246.

65 J.N. Behrman, National Interests and the Multinational Enterprise..., s. 32-87. 
Taki rozwój sytuacji rodził poczucie, że interesy korporacji amerykańskich mogą pozostawać $\mathrm{w}$ sprzeczności z celami danego państwa, a nawet w jakimś stopniu zagrażać jego suwerenności. Dane na temat dużego udziału firm amerykańskich w poszczególnych sektorach produkcji czy informacje o przejęciu przedsiębiorstw przyciągały uwagę opinii publicznej. W Europie występowała wyraźna tendencja do „upolityczniania" tego problemu. Było to często skuteczne narzędzie wywierania presji na firmy, gdy rząd chciał je nakłonić do zmiany strategii na bardziej korzystną dla gospodarki danego kraju. Jednak te naciski nie mogły być zbyt daleko idące, jeżeli decydenci chcieli zatrzymać inwestora, który zwiększał szanse rozwojowe państwa. Równoważenie tych wszystkich racji było niezwykle skomplikowane i bardzo indywidualne w przypadku każdego państwa członkowskiego EWG. Dlatego nie wprowadzono wspólnotowej polityki regulującej zasady inwestycji zagranicznych z krajów trzecich.

Pisząc o nieporozumieniach między Amerykanami a Europejczykami związanych z aktywnością korporacji międzynarodowych, należy przedstawić różnice w postrzeganiu reguł ich działalności. Europejczycy kierowali się w tym przypadku zasadą terytorialności (territorial principle), mówiącą, że każdy kraj jest suwerenny na swoim terytorium. Wobec tego rząd Stanów Zjednoczonych nie mógł narzucać żadnych reguł (np. wprowadzania określonych sankcji) filiom przedsiębiorstw amerykańskich, gdyż oznaczałoby to pogwałcenie suwerenności kraju, w którym działały.

Stany Zjednoczone przyjęły natomiast zasadę pochodzenia narodowego (nationality principle), wedle której rząd mógł regulować działania tych firm także za granicą. W 1965 roku do prawa o relacjach zagranicznych (Foreign Relations Law) wprowadzono zapis, że przedsiębiorstwo nie może, dziatając na terenie innego państwa, omijać regulacji państwa, $z$ którego pochodzi $i^{66}$. Zasada oceny efektów (effects doctrine) mówiła o konieczności kontroli działań firm za granicą, które mogły mieć wpływ na sytuację gospodarczą na terytorium USA. Zasada ta była stosowana, gdy podejrzewano łamanie prawa antymonopolowego, według którego przedsiębiorstwo nie mogło angażować się w posunięcia niekorzystne dla handlu wewnętrznego i zagranicznego. Za nielegalne uznawane były działania, w wyniku których mogło dojść do stworzenia monopolu. Istniało również europejskie prawo antymonopolowe, nie było ono jednak tak restrykcyjne jak amerykańskie. Choć traktat rzymski zabraniał tworzenia karteli eksportowych przez państwa członkowskie, nie określono w nim ograniczeń dla państw trzecich. Uznawano nawet koncentrację za pożądaną, jeśli przyczyniała się do wzrostu produktywności, wzrostu gospodarczego i awansu technologicznego ${ }^{67}$.

Chęć bezwzględnego egzekwowania prawa antymonopolowego przez rząd USA powodowała napięcia międzyrządowe. Żądano przesyłania pełnej dokumentacji od firm działających w Europie, które były w 100\% własnością Amerykanów. Obserwowano też uważnie spółki typu joint ventures. Obawiano się, że duże spółki, np. Chrysler-Simca czy GE-Olivetti, mogą przyczyniać się do zmniejszenia się konkurencyjności innych amerykańskich firm. Jednak rządy państw europejskich postrzegały taką kon-

\footnotetext{
66 Cyt. za: K. Rodman, Sanctions Beyond Borders..., s. 26.

67 Tamże, s. 23-37.
} 
centrację jako pozytywną, więc w momencie sprzeciwu odpowiedzialnego za przestrzeganie prawa antymonopolowego Departamentu Sprawiedliwości dochodziło do sporów ${ }^{68}$. Administracja Stanów Zjednoczonych była w stanie wymuszać przestrzeganie tych zasad jeszcze w latach 50. i 60. XX wieku, lecz już w kolejnej dekadzie trudno było to osiągnąć. Unikano wywoływania konfliktów międzyrządowych z tego powodu. Obawiano się, że Kongres, nie biorąc pod uwagę długofalowych skutków politycznych i gospodarczych, mógł uznać za stosowne uchwalenie środków odwetowych wobec krajów europejskich. Większą popularność mogły zyskać też ustawy o charakterze protekcjonistycznym. Także rządy krajów europejskich unikały potencjalnie szkodliwej dla sojuszu atlantyckiego konfrontacji.

Również w Stanach Zjednoczonych spadało poparcie dla inwestycji zagranicznych, ze względu na odpływ kapitału i miejsc pracy. $Z$ transatlantyckim handlem i inwestycjami nierozerwalnie była połączona kwestia światowego systemu monetarnego. Już w latach 60. można było bowiem zauważyć oznaki kryzysu systemu z Bretton Woods ${ }^{69}$. Było oczywiste, że nie był on adekwatny do potrzeb gospodarki światowej. Powodowały to w dużej mierze dwa czynniki. Pierwszym z nich był brak wystarczających rezerw złota na rynku światowym, występujący z powodu niezwykle dynamicznego wzrostu wymiany. Drugim powodem był koniec hegemonii Stanów Zjednoczonych w gospodarce światowej. Wobec tego z coraz większą niechęcią godziły się one na oparcie światowego systemu monetarnego na ich walucie. Miało to bowiem negatywne skutki dla wewnętrznej sytuacji w USA ze względu na powiększający się z tego powodu deficyt bilansu płatniczego. Obawy związane z wywozem kapitału z USA były spowodowane również powstaniem w latach 60. tzw. rynku eurodolarów. W Europie Zachodniej, w przeciwieństwie do Stanów Zjednoczonych, były bardzo wysokie stopy procentowe, co przyciągało na Stary Kontynent pokaźny międzynarodowy kapitał. To z kolei powodowało napięcia w międzynarodowym systemie monetarnym ${ }^{70}$.

W latach 1950-1968 amerykańskie BIZ w Europie wzrosły ponad 11-krotnie: z 1,7 mld USD do ponad 19 mld USD ${ }^{71}$. Rząd USA starał się je ograniczyć, gdyż powodowały one deficyt w bilansie płatniczym. Już w 1965 roku wprowadzono dobrowolny

68 J.N. Behrman, National Interests and the Multinational Enterprise..., s. 199-223.

69 Z inicjatywy Stanów Zjednoczonych zwołano w lipcu 1944 roku w Bretton Woods konferencję Narodów Zjednoczonych poświęconą zagadnieniom finansowym i walutowym. Ustalono, że waluty państw przystępujących do porozumienia mogły być wymienialne na złoto dopiero po ich wymianie na dolary. Wymienialność na złoto, w relacji 35 USD za uncję, zastrzeżono jedynie dla dolara amerykańskiego. System ten, zapewniając gospodarce światowej pieniądz międzynarodowy, ułatwiał obrót towarów i kapitału pomiędzy poszczególnymi krajami. Dopiero w 1958 roku europejskie waluty stały się wymienialne.

70 R.A. Pastor, Congress and the Politics of U.S. Foreign Economic Policy (1929-1976), Berkeley 1980, s. 207; C.F. Bergsten, Toward a New International Economic Order. Selected Papers of C.F. Bergsten, 1972-1974, Lexington 1975, s. 313. Zob. także: FRUS 1969-1976, Vol. 3: Foreign Economic Policy, 1969-1979, International Monetary Policy, 1969-1972, Government Printing Office, Washington D.C. 2002, streszczenie raportu na temat amerykańskiego bilansu płatniczego, dok. 1, dostępne także na stronie: www.state.gov/r/pa/ho/frus/nixon, 22 IV 2014.

71 J.N. Behrman, National Interests and the Multinational Enterprise..., s. 90. 
program powstrzymywania odpływu kapitału (Voluntary Credit Restraint Program). Rząd zwrócił się do międzynarodowych korporacji, by odroczyły „marginalne” inwestycje zagraniczne lub zrezygnowały z nich. Zachęcał je również, by na finansowanie działalności za granicą pożyczały pieniądze w instytucjach krajów przyjmujących, by uniknąć ich odpływu z USA. Najbardziej restrykcyjnym środkiem był program kontroli inwestycji zagranicznych wprowadzony przez prezydenta Lyndona B. Johnsona w styczniu 1968 roku, według którego amerykańskie BIZ w Europie mogły być dokonywane wyłącznie z dochodów i funduszy uzyskanych za granicą. Przedsiębiorstwa posiadające więcej niż 10\% inwestycji za granicą nie mogły angażować się w transakcje transferu kapitału do innego kraju bez pozwolenia sekretarza handlu, który mógł nakazać „sprowadzenie” zarobionych środków do USA ${ }^{72}$.

Decyzja ta, podjęta przez Johnsona w ostatnim roku urzędowania, została bardzo źle przyjęta przez korporacje ponadnarodowe. Kłóciła się też z tradycyjną wizją amerykańskiego liberalizmu gospodarczego i uderzała szczególnie w kraje najlepiej rozwinięte. Ich gospodarki, np. brytyjska, były bardzo uzależnione od dużych inwestycji. Mimo to amerykańskie korporacje nie podjęły zorganizowanej akcji przeciw ustawie i dostosowały się do jej wymogów ${ }^{73}$. Zachęcone przez administrację pożyczały środki na inwestycje w europejskich bankach. Także rządy europejskie zbyt mocno nie oponowały, gdyż wcześniej naciskały na Waszyngton, by wprowadził środki w celu zmniejszenia amerykańskiego deficytu bilansu płatniczego, a ustawa z 1968 roku była właśnie jednym z nich ${ }^{74}$.

Przed wprowadzeniem tej ustawy odpływ kapitału do EWG był większy niż dochody z tych inwestycji wracające do USA o ok. 500-800 mln USD. Sytuacja ta uległa zmianie w 1968 roku: odpływ kapitału ze Stanów Zjednoczonych wynosił $425 \mathrm{mln}$ USD, a napływ był już większy - $438 \mathrm{mln}$ USD $^{75}$. Między 1960 a 1969 rokiem roczna stopa przychodów zagranicznych filii międzynarodowych przedsiębiorstw pochodzących z USA na całym świecie wynosiła 11,1\%, a wzrost dochodów po opodatkowaniu - 6,1\%. Te dochody nie wynikały, jak się powszechnie sądzi, z eksploatacji i przetwarzania ropy w krajach nisko rozwiniętych. Do końca 1969 roku tylko 8\% dochodów przynosiło górnictwo i hutnictwo, a nakłady związane z ropą stanowiły $28 \%$ całości bezpośrednich inwestycji przedsiębiorstw międzynarodowych. Blisko $75 \%$ wynosiły inwestycje w fabryki i przedsiębiorstwa handlowe, przy czym niemal wszystkie były ulokowane w Europie Zachodniej ${ }^{76}$.

BIZ państw europejskich w Stanach Zjednoczonych wykazywały tendencję rosnącą (wzrost w latach 1950-1968 z 3,3 mld USD do 10,8 mld USD). W 1967 roku euro-

72 Tamże.

73 Tylko 5\% przedsiębiorców w anonimowej ankiecie odmówiło podporządkowania się decyzji administracji.

74 J.N. Behrman, National Interests and the Multinational Enterprise..., s. 93.

75 National Archives and Record Administration, College Park, MD, Nixon Presidential Materials Staff, NSC Institutional „H” Files, Study Memorandums (1969-1974), analiza Departamentu Stanu, aneks I: relacje gospodarcze między USA a EWG, 21 IV 1970, box H-164.

76 E.R. Goodman, The Fate of the Atlantic Community, s. 453. 
pejskie spółki po raz pierwszy zwiększyły inwestycje bezpośrednie w USA procentowo więcej, niż amerykańskie firmy zwiększyły swoje w Europie (do 1969 roku wartość aktywów posiadanych przez Europejczyków w USA wzrosła o 1/5, a amerykańskich o 1/10), ale wartość inwestycji pochodzących ze Stanów Zjednoczonych i tak aż do 1970 roku była dwukrotnie większa ${ }^{77}$.

W latach 70. firmy europejskie były w większym stopniu zdolne konkurować z tymi amerykańskimi, które traciły pozycje monopolistów w niektórych sektorach przemysłu. Przedsiębiorstwa z krajów EWG coraz częściej nawiązywały bliską współpracę, by zwiększyć zyski i walczyć z "gospodarczą kolonizacją” USA. Przyczyniało się to do umacniania integracji: koordynacji produkcji, wprowadzania korzystnych warunków dostępu do zagranicznych rynków, inicjowania wspólnych programów badawczo-rozwojowych ${ }^{78}$. Już w 1968 roku liczba nowych filii z USA po raz pierwszy była mniejsza (422) niż z innych krajów europejskich $(565)^{79}$. Liczby te nie odzwierciedlają jednak ich zasięgu i wielkości - pod tym względem nadal przewagę miały firmy zza oceanu. Należy wszakże stwierdzić, że pod koniec lat 70. nastąpiło osłabienie pozycji firm amerykańskich w Europie, ze względu na kryzys i konkurencję państw europejskich i Japonii.

\section{INWESTYCJE USA WE FRANCJI ZA PREZYDENTURY CHARLES'A DE GAULLE'A}

Spośród krajów EWG szczególnie niechętny stosunek wobec inwestycji amerykańskich miała Francja za prezydentury Charles’a de Gaulle’a. Na początku jego rządów władze francuskie starały się przyciągnąć kapitał amerykański, zakładając, że gospodarkę można było pobudzić przez zachęcanie do konkurowania na rynku. Sytuacja zmieniła się w latach 1962-1963, kiedy nastąpiły grupowe zwolnienia w fabrykach General Motors i Remington Rand. Doszło wówczas do zdecydowanych protestów związków zawodowych. Ich przywódcy twierdzili, że stało się to na polecenie centrali z USA, co oznaczało, że polityka prowadzona z innego państwa miała destrukcyjny wpływ na porządek społeczny i stabilność gospodarczą Francji. Minister przemysłu Michel Maurice-Bokanowski zapowiedział wtedy, że przyszłe inwestycje pochodzące ze Stanów Zjednoczonych będą dokładnie rozważane i monitorowane. Podkreślit, że firma Remington Rand zbudowała fabrykę dzięki pożyczkom rządu francuskiego ${ }^{80}$.

Kolejnym zdarzeniem, na które zareagowali politycy, był zakup w styczniu 1963 roku przez amerykańskiego Chryslera pakietu kontrolnego firmy Simca - trzeciego co

\section{Tamże, s. 455.}

78 Należy się zgodzić z Ernstem Haasem, który podkreślił, że głównym celem szefów wielkich firm europejskich nie było umacnianie integracji, tylko pomnażanie zysku, a także zwiększanie siły nacisku na decydentów, by wprowadzali prawa ułatwiające im rozszerzanie działalności w granicach EWG (cyt. za: W. Feld, Political Aspects of Transnational Business Collaboration in the Common Market, „International Organization” 1970, Vol. 24, nr 2, s. 223-224).

79 Tamże, s. 220.

80 R.F. Kuisel, Seducing the French..., s. 156. 
do wielkości producenta samochodów we Francji. Minister finansów Valéry Giscard d'Estaing stwierdził, że nie można było dopuścić do sytuacji, w której ważne sektory Wspólnego Rynku w dużej mierze były zależne od decyzji podejmowanych w innym kraju. Prowadził intensywne rozmowy ze swoimi odpowiednikami w EWG, chcąc przekonać ich do wprowadzenia wspólnych ograniczeń dla inwestycji. Jednak nie udało mu się przeforsować tego projektu, tym bardziej że pozostali przywódcy dystansowali się od Francji, z powodu weta de Gaulle'a wobec przystąpienia Wielkiej Brytanii do Wspólnoty ${ }^{81}$. Spekulowano nawet, że jednym z powodów jego zgłoszenia było rosnące zaniepokojenie społeczne we Francji negatywnymi skutkami amerykańskich inwestycji. Rządzący dążyli do pogłębiania gospodarczej integracji europejskiej i ograniczania uzależnienia na tym polu od Stanów Zjednoczonych.

Zaufanie do amerykańskich firm dodatkowo spadło, a konflikt przeniósł się na poziom międzyrządowy, gdy w 1964 roku rząd USA zakazał francuskiej filii koncernu IBM sprzedaży komputerów, które miały być używane przez władze w Paryżu do obsługi programu nuklearnego. Problem został rozwiązany dopiero po dwóch latach, gdy Amerykanie zgodzili się na ich używanie do celów pokojowych ${ }^{82}$.

Ponieważ inne państwa EWG nie chciały podjąć wspólnej akcji ograniczającej inwestycje amerykańskie, Francuzi stworzyli niezależnie listę sektorów, które uznali za strategiczne. Gdy przedsiębiorstwo zagraniczne zgłaszało chęć inwestycji w któryś z nich, rząd badał przewidywany wpływ takiego przedsięwzięcia na gospodarkę, wstrzymując zgodę na jego rozpoczęcie do czasu rozpatrzenia sprawy. Działalność firm międzynarodowych była przez to znacznie utrudniona. Każdy przypadek był rozpatrywany osobno, co pochłaniało mnóstwo czasu. Zniechęcało to przedsiębiorców, którzy uznawali Francję za kraj najmniej przyjazny inwestycjom, dlatego rezygnowali z nowych projektów, a nawet zaczęli przenosić się do innych krajów EWG. Przyzwyczajeni do szybkich procedur Amerykanie zareagowali bardzo sprawnie. Na przykład firma Ford zrezygnowała z budowy fabryki w Metz, decydując się na ulokowanie tego przedsięwzięcia w Saarlouis w RFN. Podobnie Philips Petroleum przeniosła planowane inwestycje do Holandii, rezygnując z Bordeaux.

Rosnąca niechęć Francuzów wobec przedsiębiorców amerykańskich była podsycana przez rząd i media. Następowało bardzo niekorzystne upolitycznienie tej sprawy. Można to zilustrować na przykładzie koncernu Libby, producenta żywności konserwowej. W 1963 roku firma podpisała kontrakt z francuskim Ministerstwem Rolnictwa, zobowiązując się do budowy dużej fabryki w regionie Languedoc-Roussillon w środkowej Francji, w której będzie przetwarzała lokalne warzywa i owoce, eksportując $85 \%$ produkcji. Rolnicy mieli jednak uprawiać je według wytycznych i standardów narzuconych przez firmę, co wzbudziło ich sprzeciw. Także francuscy producenci puszek uzna-

8114 I 1963 r. francuski prezydent ogłosił, że Francja zawetuje wniosek Londynu o przystąpienie do EWG. Uważał, że po przyłączeniu Wielkiej Brytanii EWG stanie się ogromna wspólnotą atlantyckq zależna od Stanów Zjednoczonych, co jest przeciwieństwem francuskich dążeń $i$ czysto europejskiego charakteru Wspólnoty (Extracts from de Gaulle's Veto, [w:] Documents on European Union, red. A.G. Harryvan, J. Van der Harst, Houndmills 1997, s. 37-41, Documents in History Series). 
li, że nie byli w stanie konkurować z amerykańskim potentatem. Sprawa została nagłośniona w prasie i pod wpływem społecznego nacisku rząd francuski zmusił Libby, by część swoich udziałów odsprzedała bankowi francuskiemu i dała rolnikom lepsze kontrakty ${ }^{83}$.

Choć pojawiały się głosy ekonomistów i przedsiębiorców, że takie zaangażowanie rządu jest niekorzystne dla francuskiej gospodarki, rząd nie rezygnował z restrykcyjnych działań, a prasa podtrzymywała duże zainteresowanie opinii publicznej tą sprawą. Nie wprowadzono jednak żadnej ustawy ograniczającej inwestycje, mimo nacisków lewicy w parlamencie. Rząd kontynuował uciążliwe monitorowanie nowych przedsięwzięć. Wkrótce straty dla francuskiej gospodarki były ewidentne. Francuskie firmy w niektórych sektorach nie potrafiły zastąpić amerykańskich, które przenosiły się do innych krajów europejskich. Francja traciła na dochodach z podatków, eksportu, znikały miejsca pracy i możliwości transferu technologii. Wartość BIZ zaczęła spadać, począwszy od 1965 roku. Wtedy ukazał się alarmistyczny raport przygotowany przez grupę ekonomistów, biznesmenów i bankierów, wskazujący na straty gospodarki francuskiej i rosnącą lukę technologiczną. Stwierdzono, że w gospodarce światowej wielkie przedsiębiorstwa zyskiwały dominującą rolę, z czego wysnuto wniosek, że lepszą opcją dla firm francuskich było, gdy prosperowaty, nawet pod kontrola amerykanska, niż znikaty zrynku, wymachujac francuskim sztandarem ${ }^{84}$.

De Gaulle miał jednak inne zdanie. Jego polityka wpłynęła na pogorszenie się pozycji USD, gdy zdecydował się na wymianę tej waluty uzyskanej z nadwyżki handlowej na złoto. W 1965 roku rząd francuski dokonał wymiany $300 \mathrm{mln} \mathrm{USD}^{85}$. De Gaulle wzywał do powrotu do parytetu złota i „detronizacji” dolara jako światowej waluty rezerwowej. Twierdził, że dzięki temu skończyłaby się dominacja amerykańskich firm na rynku światowym, co zrównałoby szanse konkurencji przedsiębiorstw europejskich ${ }^{86}$. Francuski prezydent starał się pozyskać poparcie RFN i nawiązać z tym państwem ścisłą współpracę w nauce, technologii i przemyśle, by zmniejszyć europejską zależność od USA na tych polach ${ }^{87}$. Jednakże RFN nie była chętna do przyjęcia ostentacyjnie

83 R.F. Kuisel, Seducing the French..., s. 164-165.

84 Tamże, s. 171.

85 T. Kemp, The Climax of Capitalism. The U.S. Economy in the Twentieth Century, New York 1990, s. 189.

86 Na przykład General Motors Corporation, nie mogąc zainwestować we Francji, przeniosła fabryki do Belgii.

8722 I 1963 r. de Gaulle podpisał z Adenauerem porozumienie o współpracy między Francją a RFN, zwane traktatem elizejskim. Układ ten przewidywał częste konsultacje szefów rządów i dowódców sił militarnych obu państw, a także współpracę w dziedzinie gospodarczej, kulturalnej i naukowej. Tak daleko idące zbliżenie w dobie ostrej krytyki przez de Gaulle’a polityki USA mogło być odebrane za oceanem jako przedsięwzięcie o ostrzu antyamerykańskim. Bundestag wprawdzie zgodził się na przyjęcie porozumienia z Francją, ale dodał do niego preambułę, w której podkreślono związki RFN z USA i NATO, a także wypowiedziano się za włączeniem w struktury zjednoczonej Europy Wielkiej Brytanii. Zastrzeżenia parlamentu RFN osłabiły wymowę traktatu elizejskiego. Zob. P. Matera, R Matera, Stany Zjednoczone i Europa. Stosunki polityczne i gospodarcze. 1776-2004, Warszawa 2007, s. 234-235. 
antyamerykańskiej polityki. Stało się to także pod naciskiem rządu Stanów Zjednoczonych, który przypominał, że siły amerykańskie stacjonowały w tym kraju, dopóki RFN była gotowa do pomocy w zmniejszaniu amerykańskiego deficytu bilansu płatniczego $^{88}$. Posunięcia de Gaulle’a wywołały bardzo ostre reakcje w amerykańskim Kongresie. Pojawiły się nawet postulaty, by zmusić Francję do spłacenia długu zaciągniętego w czasie I wojny światowej. Opinia publiczna zagroziła bojkotem francuskich produktów; dochodziło do demonstracyjnego wylewania wina do kanalizacji. Jednak amerykański prezydent - Lyndon B. Johnson, chcąc uniknąć pogorszenia stosunków z sojusznikiem, nie wypowiadał się oficjalnie w tej sprawie.

Charakterystyczne dla połowy lat 60. XX wieku obawy i ambicje Europejczyków przedstawił wydawca paryskiego tygodnika „L'Express” Jean-Jacques Servan-Schreiber w wydanej w 1967 roku książce American Challenge (Amerykańskie wyzwanie). Udowadniał w niej, że Europa Zachodnia stała się „kolonią” Stanów Zjednoczonych, gdyż jej obszar został praktycznie zaanektowany pod względem gospodarczym przez amerykańskie przedsiębiorstwa. Servan-Schreiber przewidywat, że amerykański przemysł w Europie stanie się trzecią co do wielkości światową siłą gospodarczą. Apelował, by Europejczycy zmienili ten stan rzeczy, ucząc się od obywateli zza oceanu sposobów na gospodarczą wydajnośćc ${ }^{89}$. Książka stała się bestsellerem: do końca 1967 roku sprzedano 400 tysięcy jej egzemplarzy.

Wprowadzając strategię ograniczania ekspansji amerykańskiego kapitału, de Gaulle liczył na wzmocnienie swej pozycji we Francji i zyskanie poparcia społecznego koniecznego do realizacji różnych celów, nie tylko związanych z polityką gospodarczą. Można jednak stwierdzić, że zdając sobie sprawę ze strat, od 1966 roku rząd francuski ograniczył zakres kontroli inwestycji, zachęcając przedsiębiorców do powrotu. Następca de Gaulle’a - Georges Pompidou, już nie traktował sprawy działalności korporacji międzynarodowych jako kwestii politycznej. Podczas wizyty w Paryżu w 1970 roku prezydenta Stanów Zjednoczonych Richarda Nixona, który wziął udział w spotkaniu z biznesmenami, Pompidou zadeklarował, że będzie dążył do poprawy warunków inwestowania we Francji. Zaznaczył przy tym, że również przedsiębiorstwa francuskie planowały ekspansję na rynki światowe, co można było odczytać jako zapowiedź konkurowania o rynki inwestycji na całym świecie ${ }^{90}$.

\section{PODSUMOWANIE}

W latach 60. i 70. XX wieku przedsiębiorstwa międzynarodowe zyskiwały coraz większe znaczenie w gospodarce światowej. Jednak wciąż państwa narodowe pozostawały kluczowymi aktorami. Vernon zauważył, że nawet niewielkie i słabe kraje przyjmujące inwestycje mogą pokrzyżować interesy potężnych międzynarodowych

\footnotetext{
88 R. Gilpin, US Power and the Multinational Corporation..., s. 415.

89 J.-J. Servan-Schreiber, The American Challenge, New York 1968, passim.

90 R.F. Kuisel, Seducing the French..., s. 180.
} 
korporacji. Jednak w pracy pod znamiennym tytułem Sovereignty-at-Bay (Zagrożona suwerenność), wydanej w 1971 roku, przewidywał zderzenie dwóch sił: systemu państw narodowych, których zadaniem jest zabezpieczenie interesów obywateli, i systemu przedsiębiorstw reagujących na rosnące możliwości zysku pojawiające się wraz z postępem technologicznym. Stwierdził, że istniejące instytucje międzynarodowe nie radziły sobie z tym problemem, a brak skoordynowanych działań mógł okazać się destrukcyjny ${ }^{11}$.

Mimo dominującej roli państw ${ }^{92}$ wielkie korporacje zaczęły być w większym stopniu uwzględniane w badaniach relacji międzynarodowych. Amerykańscy naukowcy Robert Keohane i Joseph Nye wypracowali teorię złożonej współzależności (complex interdependence), która podważała główne założenia realizmu. Twierdzili, że nie tylko stosunki międzypaństwowe, ale także działania innych aktorów wpływają na rządy i osłabiają ich zdolność autonomicznego kształtowania stosunków międzynarodowych. Keohane i Nye obalali przekonanie o hierarchiczności podziału polityki na priorytetową high politics odnoszącą się do bezpieczeństwa i drugorzędną low politics relacji handlowych, nazywając ten podział anachronicznym. Badacze twierdzili, że trudno określić jakąkolwiek transakcję jako czysto rynkową, gdyż odbywa się ona w określonym systemie politycznym i gospodarczym. Im lepiej te systemy działają, tym mniej kwestie polityczne oddziałują na ekonomiczne. Jeśli jednak występują spory i pojawia się niewydolność systemu uniemożliwiająca ich rozwiązanie, decyzje podejmują politycy. Nieunikniona jest wtedy eskalacja rozbieżności. Mamy do czynienia z coraz większą liczbą kwestii spornych, wzrasta zainteresowanie tymi problemami na najwyższym szczeblu władz państwowych, co z kolei często prowadzi do pogorszenia się relacji politycznych. Dążenie do ich poprawy jest niewątpliwie czynnikiem hamującym eskalację konfliktu gospodarczego i bodźcem do podjęcia negocjacji w celu osiągnięcia kompromisu. Keohane i Nye odnosili te konkluzje zarówno do relacji międzynarodowych, jak i wewnętrznych. Wysunęli również tezę, że wzrastające upolitycznienie międzynarodowych relacji gospodarczych wynika z faktu, że coraz częściej ekonomiczne narzędzia nacisku były stosowane w polityce zagranicznej. Amerykańscy autorzy stwierdzili, że państwo nadal odgrywało dominującą rolę w międzynarodowych stosunkach gospodarczych, a stosowanie przez nie narzędzi politycznych było kluczowe ${ }^{93}$.

Gilpin przyznawał, że korporacje międzynarodowe zyskiwały coraz większą swobodę działania, ale to wciąż państwa narodowe były decydentami. Podkreślał, że interesy i polityka państw są zdeterminowane przez rządzącą elitę polityczną, która niekiedy mogła ulegać naciskom tych korporacji, jeśli ich interesy były zbieżne ${ }^{94}$. Dodawał, że

91 R. Vernon, Sovereignty-at-bay. The Multinational Spread of U.S. Enterprises, New York 1971, Harvard Multinational Enterprise Series.

92 Stephen Krasner uważał, że wzrost aktywności przedsiębiorstw międzynarodowych był rezultatem zmian interesów państw, które same kształtowały międzynarodowy biznes (S. Krasner, Defending the National Interest. Raw Materials, Investment and American Foreign Policy, Princeton, N.J. 1978).

93 R. Keohane, J. Nye, Power and Interdependence. World Politics in Transition, Boston 1977, s. 29-36.

94

R. Gilpin, US Power and the Multinational Corporation..., s. 19, 86. 
integracja gospodarcza sprawiała, iż próby powstrzymania korporacji międzynarodowych były nieskuteczne. Jedyną możliwością ograniczenia ich działalności, choć w tamtym czasie mało prawdopodobną, była skoordynowana akcja wszystkich krajów EWG. Jednak również w tej kwestii grały rolę względy polityczne. Można było założyć, że RFN, polegająca na Stanach Zjednoczonych w kwestiach obronnych, będzie blokować niekorzystne dla Amerykanów decyzje pozostałych członków EWG ${ }^{95}$.

W kolejnych latach kraje przyjmujące dążyły do uzyskania większego wpływu na międzynarodowe korporacje, poddając je regulacjom wewnętrznym, wobec niemożności wypracowania międzynarodowego prawa określającego ramy ich działalności. Malały możliwości kontroli rządów krajów pochodzenia korporacji, gdyż coraz trudniejsza stawała się ich identyfikacja z konkretnym państwem ${ }^{96}$. Od lat 80 . XX wieku państwa, szczególnie te bardziej rozwinięte, oddawały pole gospodarcze przedsiębiorstwom. Wynikało to z wprowadzania nowych zasad deregulacyjnych, liberalizacji przepisów, prywatyzacji przedsiębiorstw, otwierania się kolejnych gospodarek na zagraniczne inwestycje (np. byłych krajów obozu socjalistycznego po zimnej wojnie). Wpływy na rynki finansowe, dostęp do informacji, wiedzy i technologii - czynniki zapewniające rozwój gospodarczy - w coraz większym stopniu stawały się atrybutami korporacji, a nie rządów.

\section{BIBLIOGRAFIA}

Akard P.J., Corporate Mobilization and Political Power. The Transformation of U.S. Economic Policy in the 1970s., „American Sociological Review” 1992, Vol. 57, nr 5.

Behrman J.N., National Interests and the Multinational Enterprise. Tensions Among the North Atlantic Countries, Eaglewood Clifs 1970.

Bergsten C.F., Toward a New International Economic Order. Selected Papers of C.F. Bergsten, 1972-1974, Lexington 1975.

Congressional Record. Proceeding and Debates of the First Session of the 93rd Congress, [online] http://www.archive.org/stream/congressionalrec119qunit/congressionalrec119qunit_ djvu.txt.

Cowan E., The Gasoline Shortage. Real or Contrived?, „New York Times” 1973, 8 VI.

Diebold W. Jr., U.S. Trade Policy. The New Political Dimension, „Foreign Affairs” 1974, Vol. 52, $\mathrm{nr} 3$.

Elia C.J., Europeans, Japanese Find the Time is Ripe to Acquire US Firms, „Wall Street Journal” 1973, 22 IV.

Feld W., Political Aspects of Transnational Business Collaboration in the Common Market, „International Organization" 1970, Vol. 24, nr 2.

Gannon J., High Level Friends, „Wall Street Journal” 1972, 13 I.

95 Tenże, Three Models of the Future, [w:] Key Concepts in International Political Economy, Vol. 1, red. D.A. Baldwin, Vermont 1993, s. 45.

96 G. Jones, Nationality and Multinationals... 
Gilpin R., Global Political Economy. Understanding the International Economic Order, Princeton 2001.

Gilpin R., Three Models of the Future, [w:] Key Concepts in International Political Economy, Vol. 1, red. D. Baldwin, Vermont 1993.

Gilpin R., US Power and the Multinational Corporation. The Political Economy of Foreign Direct Investment, New York 1975.

Goodman E.R., The Fate of the Atlantic Community, New York 1975, Praeger Special Studies in International Politics and Government.

Goodman E.R., The Impact of the Multinational Enterprise upon Atlantic Community, [w:] The New Europe and the U.S. Partners or Rivals, red. G. Mally, Lexington 1974, Lexington Books.

Harryvan A.G., Van der Harst J. (red.), Documents on European Union, New York 1997, Documents in History Series.

Holzman F.D., Legvold R., The Economics and Politics of East-West Relations, „International Organization" 1975, Vol. 29, nr 1.

Hymer S., International Operations of National Firms. A Study of Direct Foreign Investment, Cambridge 1976, MIT Monographs in Economics, 14.

Ikenberry J., Lake D.A., Mastanduno M., Introduction. Approaches to Explaining American Foreign Economic Policy, „International Organization” 1988, Vol. 42, nr 1.

Janssen R.F., Multinationals Face Disorderly Struggle Over Foreign Controls, Conference Finds, „The Wall Street Journal” 1973, 8 I.

Jarczewska-Romaniuk A., Relacje polityki i ekonomii w procesie globalizacji, [w:] Globalizacja a stosunki międzynarodowe, red. E. Haliżak, R. Kuźniar, J. Symonides, Bydgoszcz-Warszawa 2004.

Jones G., Nationality and Multinationals in Historical Perspective, [online] http://www.hbs. edu/faculty/Publication\%20Files/06-052.pdf.

Kaiser K., Transnational Relations as the Threat to the Democratic Process, „International Organization" 1971, Vol. 25, nr 3.

Kaliński J., Zarys historii gospodarczej XIX i XX w., Warszawa 2000.

Kemp T., The Climax of Capitalism. The U.S. Economy in the Twentieth Century, New York 1990.

Keohane R., Nye J., Power and Interdependence. World Politics in Transition, Boston 1977.

Keohane R., V.D. Ooms, The Multinational Enterprise and World Political Economy, „International Organization" 1975, Vol. 26, nr 1.

Keohane R., V.D. Ooms, The Multinational Firm and International Regulations, [w:] World Politics and International Economics, red. C.F. Bergsten, L.B. Krause, Washington 1975.

Kneelands D., Energy. Many Skeptical on Reasons of Crisis, „New York Times” 1973, 23 XII.

Korbin S.J., Sovereignty@Bay. Globalization, Multinational Enterprise, and the International Political System, [w:] Oxford Handbook of International Business, red. A.M. Rugman, T.L. Brewer, Oxford 2009.

Krasner S., Defending the National Interest. Raw Materials, Investment and American Foreign Policy, Princeton, N.J. 1978.

Kuisel R.F., Seducing the French. The Dilemma of Americanization, Berkeley 1993. 
Magdoff H., The Age of Imperialism. The Economics of U.S. Foreign Policy, New York 1969.

Makać A., Wspótczesna gospodarka światowa. Jej istota i struktura, [w:] Przemiany we wspótczesnej gospodarce światowej, red. nauk. E. Oziewicz, Warszawa 2006.

Matera P., Uwarunkowania ekonomiczne polityki Stanów Zjednoczonych wobec Europy Zachodniej za prezydentury Richarda M. Nixona (1969-1974), Łódź 2012.

Matera P., Matera R., Stany Zjednoczone i Europa. Stosunki polityczne i gospodarcze. 1776-2004, Warszawa 2007.

Multinational Corporations in World Development, United Nations, Department of Economic and Social Affairs, [online] http://unctc.unctad.org/data/e73iial1a.pdf.

National Archives and Record Administration, College Park, MD, Nixon Presidential Materials Staff, NSC Institutional „H” Files, Study Memorandums (1969-1974).

Nolan M., The Transatlantic Century. Europe and America, 1890-2010, Cambridge 2012, New Approaches to European History, 46.

Nye J.S., Multinationals. The Game and the Rules. Multinational Corporations in World Politics, „Foreign Affairs” 1974, Vol. 53, nr 1.

Panitch L., Konings M., Demystifying Imperial Finance, [w:] American Empire and the Political Economy of Global Finance, red. L. Panitch, M. Konings, New York 2008, International political economy series (Palgrave Macmillan (Firm)).

Pastor R.A., Congress and the Politics of U.S. Foreign Economic Policy (1929-1976), Berkeley 1980.

Policy Aspects of Foreign Investment by US Multinational Corporations, [w:] The Multinational Corporation. Studies on US Foreign Investment, Vol. 1, Office of International Investments, Washington 1972, United States Department of Commerce Publication.

Porter M., The Competitive Advantage of Nations, „Harvard Business Review” 1990, Vol. 68, nr 2.

Ranelagh J., The Agency. The Rise and Decline of the CIA, New York 1987.

Ray D.M., Corporations and American Foreign Relations, „The Annals of the American Academy of Political and Social Science" 1972, Vol. 403.

Rodman K., Sanctions Beyond Borders. Multinational Corporations and US Economic Statecraft, Lanham 2001.

Rostow W., The Stages of Economic Growth. A Non-Communist Manifesto, Cambridge 1960.

Rugman A., Multinationals and Canada-United States Free Trade, Columbia 1990, Critical Issues Facing the Multinational Enterprise.

Servan-Schreiber J.-J., The American Challenge, New York 1968.

Spero J.E., The Politics of International Economic Relations, New York 1999.

Staats E.B., U.S. Foreign Relations and Multinational Corporations. What's the Connection?, Report to the Congress, 23 VIII 1978, [online] http://www.gao.gov/assets/130/123830.pdf. Strange S., The Retreat of the State. The Diffusion of Power in the World Economy, New York 1996, Cambridge Studies in International Relations, 49.

Świerkocki J., Zarys międzynarodowych stosunków gospodarczych, Warszawa 2004.

Vernon R., The Economic and Political Consequences of Multinational Enterprises, Boston 1972. Vernon R., International Investment and International Trade in the Product Cycle, „Quarterly Journal of Economics" 1966, Vol. 80, nr 2. 
Vernon R., Sovereignty at Bay Ten Years After, „International Organization” 1981, Vol. 35, nr 3. Vernon R., Sovereignty-at-bay. The Multinational Spread of U.S. Enterprises, New York 1971, Harvard Multinational Enterprise Series.

Vernon R., Storm over the Multinationals. The Real Issue, Cambridge, Mass. 1977.

Dr hab. Paulina MATERA, prof. UŁ - pracownik Katedry Studiów Transatlantyckich i Mediów Masowych na Wydziale Studiów Międzynarodowych i Politologicznych Uniwersytetu Łódzkiego. Jej zainteresowania badawcze koncentrują się na obszarze międzynarodowych stosunków politycznych i gospodarczych, szczególnie polityki zagranicznej Stanów Zjednoczonych. Jest autorką monografii: Francja w polityce zagranicznej Stanów Zjednoczonych w latach 1929-1933 (2003), Stany Zjednoczone i Europa. Stosunki polityczne i gospodarcze. 1776-2004 (2007; we współautorstwie z Rafałem Materą) oraz Uwarunkowania ekonomiczne polityki Stanów Zjednoczonych wobec Europy Zachodniej za prezydentury Richarda M. Nixona (1969-1974) (2012). Opublikowała także wiele artykułów dotyczących polityki zagranicznej Stanów Zjednoczonych. 